\title{
MONRATE, a descriptive tool for calculation and prediction of re-infection of Ascaris lumbricoides
}

\author{
S.O. SAM-WOBO ${ }^{1 *}$, C.F. MAFIANA ${ }^{1}$, S.A. ONASHOGA ${ }^{2}$ and O.R. VINCENT ${ }^{2}$ \\ ${ }^{1}$ Department of Biological Sciences, University of Agriculture, PMB 2240, Abeokuta 110001, Ogun State, Nigeria \\ ${ }^{2}$ Department of Computer Sciences, University of Agriculture, PMB 2240, Abeokuta 110001, Ogun State, Nigeria
}

\begin{abstract}
The objective of the study was to develop an interactive and systematic descriptive tool, MONRATE for calculating and predicting reinfection rates and time of Ascaris lumbricoides following mass chemotherapy using levamisole. Each pupil previously treated was retreated 6 or 7 months after the initial treatment in Ogun State, Nigeria. The implementation was based on the theoretical equation for time-prevalence: $Y=G\left[1-(1-X)^{\mathrm{N}-\mathrm{R}}\right]$. Using the PsuedoCode of the MONRATE tool, the calculated monthly reinfection rates $(X)$ for the LGAs were 1.6\% in Ewekoro, 2.3\% in Odeda, 2.3\% in Ado-odo/Otta, 3.8\% in Ogun Waterside and 4.2\% in Obafemi/Owode. The mathematical mean of ' $\mathrm{X}$ ' values in the study areas for Ogun State was 2.84. The calculated reinfection time (N months) for the LGAs varied such as Ado-odo/Otta (12.7), Ogun Waterside (21.8), Obafemi/Owode (22.92), Odeda (25.45), and Ewekoro (25.9). The mean value for $\mathrm{N}$ in Ogun State was 21.75. The results obtained from MONRATE were compared with those obtained using the mathematical equation and were found to be the same but MONRATE was faster in computation and more accurate. It is concluded that MONRATE is a veritable tool that can be used in the execution of control programme involving mass treatment against $A$. lumbricoides.
\end{abstract}

Keywords: MONRATE, Ascaris lumbricoides, re-infection rate, Nigeria

\section{Introduction}

In Nigeria, intestinal parasites have continued to prevail because of low level of living standards, poor environmental sanitation and ignorance of simple health promoting factors. Although the prevalence rates of individual parasites vary considerably in different parts of the country, several studies show that Ascaris lumbricoides is the most prevalent intestinal parasite, followed by hookworms, Trichuris trichuria and Strongyloides stercoralis (Asaolu et al; 1992; Mafiana, 1995; Mafiana et al, 1998, 2000; Ogbe et al., 2002; SamWobo et al., 2004).

Epidemiological studies in urban and rural communities of Nigeria have revealed varying prevalence of helminthiasis. Okpala (1956), Obiamiwe (1977), Reinthale, et al (1988), Onadeko \& Ladipo (1989), Holland et al. (1989), Fashuyi (1992), Agi (1995), Adeyeba \& Akintobi (2002), Ozumba \& Ozumba (2002) all observed higher prevalence of Ascaris infection over hookworm and T. trichiura. However, Udonsi et al. (1980) and Suswam et al. (1992), reported higher prevalence of hookworm infection over other helminths. Similarly, Ogbe \& Adu (1990), Asaolu et al. (1992), observed higher prevalence of $T$. trichiura to both Ascaris and hookworm.

The distributions of worm numbers per host tend to be highly aggregated in form, where most individuals have few parasites and a few individuals have heavy worm burdens. Anderson (1986) and Forrester et al. (1990) had reported that helminth parasites were aggregated in human populations so that most individuals have very light infections while a few have great numbers of parasites. The degree of parasite aggregation as measured by ' $K$ ' (negative binomial parameter) had previously been reported in Nigeria (Ogbe \& Odudu 1988-90; Mafiana 1995; Mafiana et al., 1998; Sam-Wobo et al., 2004), to have values below unity for A. lumbricoides. Croll et al. (1982) had observed that worm fecundity appears to decline as burdens within an individual increases. It has been established that prevalence is a poor indicator of intensity of infection due to the high aggregate distribution of worm numbers per person where large changes in intensity is usually accompanied by small changes in prevalence (Anderson \& May (1985).

In epidemiological aspects of ascariasis control, studies have shown that the most important factor to be considered is the persistent occurrence of reinfection in endemic areas (Chai, 1983; Arfaa \& Ghadirian, 1977). The authors opined that, due to reinfection, the prevalence returned to the pre-treatment level within one year after intensive mass treatment using effective

\footnotetext{
* Correspondence: S.O.Sam-Wobo; E-mail: sam_wobo@yahoo.com
} 
antihelmintics. Therefore the success or failure in control greatly depends on the rate and frequency of reinfection.

Morishita (1972) had suggested that where prevalence and intensity of $A$. lumbricoides infection were high, the incidence (frequency) of reinfection would also be high. Observations by Chai (1983) showed that where the prevalence was $82-92 \%$, the monthly reinfection rate was $7.3-10.2 \%$, but where it was $36 \%$ the monthly rate was $3.3-4.8 \%$. However, this observation may not totally be correct since the Chai (1983) study was based on repeated egg examination after treatment and not on the worm recovery. It has been further observed that if worm collection methods were applied with mass chemotherapy using anthelmintics, the reinfection rate could be estimated simply by discriminating the cases harbouring young worm(s). The relationship between prevalence and reinfection rates in terms of all worms and young worm positive rates respectively could be applied to any given area (Chai, 1983). The objectives of the present study, therefore, was to develop an interactive and systematic tool which would be faster in computation and more accurate for calculating and predicting reinfection rates, by applying the formula of Hayashi (1977) as modified by Chai (1983) through observation of epidemiological relationship between the current prevalence and the monthly reinfection rate of $A$. lumbricoides in communities of Ogun State, Nigeria.

\section{Materials and Methods}

\section{Study area}

Ogun State lies approximately between longitude $2^{\circ} 30^{\prime} \mathrm{E}$ and $4^{\circ} 30^{\prime} \mathrm{E}$ and between latitudes $6^{\circ} 30^{\prime} \mathrm{N}$ and $8^{\circ} \mathrm{N}$. It is predominantly populated by the Yoruba speaking tribes of Nigeria whose traditional occupations are agriculture and commerce. The Study areas were mapped using the soil-geological map of Ogun State (Sam-Wobo \& Mafiana, 2004). Consent and approval to use the primary school pupils were obtained from the State Primary Education Board after explaining the objectives of the study. Letters were thereafter issued to officials of the Local Government Education Authority in the study Local Government Areas (LGA), as well as to the Headteachers in the selected primary schools for cooperation and assistance during the research study. In the four primary schools selected from each of the Local Government Areas, consent was also sought from the Parent/Teachers Association and the school children through interactive sessions facilitated by the Headteachers of each school.

\section{Prevalence and intensity by direct method}

Levamex (containing 40mg of Levamisole, UNIBIOS Laboratories Ltd, India) a broadspectrum antihelmintic was administered to all participants in the study according to manufacturer's instructions. The pupils who took the drugs in our presence, were each given a labelled screw cap plastic container, about 1.5 litres with an instruction to pass all stools for the next 24 hours into the container. Stool passed within 48hours of treatment was collected, preserved with $10 \%$ formalin and taken to the Parasitology Laboratory in the Department of Biological Sciences, University of Agriculture, Abeokuta. Examination of Ascaris was by flushing the stool with running water through a sieve. The worms present were then sorted into sexes and counted. Before fixing the worms in $10 \%$ formalin, the length $(\mathrm{cm})$ and weight $(\mathrm{g})$ were obtained for characterization into young and adult worms. The length measurement was done by tracing a flexible wire through the anterior to posterior ends and the weight was measured using Mettler P163 weighing balance by Gallenkamp.

\section{Data analysis}

SPSS version 10 employing simple percentiles, paired and sample t-tests techniques were used in analysing the prevalence and intensity of infections, in addition to comparing infections and the frequency distribution probability factor $(k)$ of the worms.

\section{Re-infection studies}

The method used for the prevalence and intensity studies was adopted. Each pupil previously treated was retreated 6 or 7 months after the initial treatment with Levamex. Thereafter, the pupils were requested to void all stools into the 1.5 litre container and bring to the school for two consecutive days. The stools were examined for young worms, which are indicative of fresh infection since the initial treatment. Using the theoretical equation of Hayashi (1977) for timeprevalence:

Where

$\mathrm{Y}=$ Prevalence

$\mathrm{X}=$ Monthly re-infection rate

$\mathrm{N}=$ Time elapsed in months

$\mathrm{R}=$ Incubation period for worm maturation 
$\mathrm{G}=$ Maximum prevalence to be reached in the area.

The above equation was modified under the consideration that ' $G$ ' should be $1(100 \%)$ and ' $R$ ' be 0 when ' $X$ ' and ' $Y$ ' values were expressed by worm positive rates as follows: $\mathrm{Y}=1$ - (1X) ${ }^{\mathrm{N}}$ (Chai, 1983).

The monthly re-infection rate therefore was obtained using the known values of ' $\mathrm{r}$ ' (Young worm positive rate) and 'N' (number in months) according to the equation

$\mathrm{Yr}=1(1-\mathrm{X})^{2}$

A tool named "MONRATE" using Q-Basic programming languages was used for the calculation and prediction of reinfection rate $(\mathrm{N})$ as a quality assurance tool for the Chai (1983) model.

\begin{tabular}{|c|c|c|}
\hline Steps & Pseudo-code & Remarks \\
\hline 1 & $\mathrm{c} / \mathrm{s}$ & Clear the screen \\
\hline 2 & Array r (20) & $\begin{array}{l}\text { A list named } r \text { containing } \\
20 \text { elements }\end{array}$ \\
\hline 3 & Array y (20) & $\begin{array}{l}\text { A list named y containing } \\
20 \text { elements }\end{array}$ \\
\hline 4 & $\begin{array}{l}\text { Do i from } 1 \\
\text { to } 20\end{array}$ & $\begin{array}{l}\text { A loop i to read each of the } \\
\text { values in } r\end{array}$ \\
\hline 5 & Read r (i) & read in each value of $r$ \\
\hline 6 & $\begin{array}{l}\text { LET x = 1 - } \\
\text { SQR }(1- \\
(r(i) / 100))\end{array}$ & $\begin{array}{l}\text { to get the monthly } \\
\text { re-infection rate }\end{array}$ \\
\hline 7 & Print $x$ & print the result of $x$ \\
\hline 8 & Next i - & get the next value of $r$ \\
\hline 9 & $\begin{array}{l}\text { Do j from } 1 \\
\text { to } 20\end{array}$ & $\begin{array}{l}\text { A loop } j \text { to read the values } \\
\text { of } y\end{array}$ \\
\hline
\end{tabular}

\begin{tabular}{|c|c|c|}
\hline 10 & Read Y(J) & read in each value of $y$ \\
\hline 11 & $\begin{array}{l}\text { LET n = LOG } \\
(1-(Y(j) / 100)) / \\
\operatorname{LOG}(1-x)\end{array}$ & $\begin{array}{l}\text { this calculates the time } \\
\text { elapsed in months }\end{array}$ \\
\hline & Print $\mathrm{n}$ & print the value of each $n$ \\
\hline & Next i & read in the next value of $y$ \\
\hline & End & end programme execution \\
\hline
\end{tabular}

Note: $\quad r$ - represents the worm positive case values

y - represents the young worm positive
case values

\section{Results}

\section{Direct prevalence and intensity of infection}

A total of 1600 pupils (51\% males: $49 \%$ females) within the age classes 6-17 years were enrolled for direct prevalence in the different LGAs, but only 990 of the pupils complied with respect to faecal collection after treatment. It was observed that Odeda LG School, Obantoko had the least compliance (19\%), while the highest compliance was in Anglican School, Obafemi (96.3\%). On the whole, there was $62 \%$ compliance.

The study observed that 480 pupils of the 990 pupils who complied with faecal collection passed out worms (Table 1). The result showed that $51.9 \%$ male and $48.1 \%$ female pupils were infected with $A$. lumbricoides. Statistical analysis showed no significant difference between the infection rates in both sexes $(t=2.60, P=0.234)$. Male pupils voided higher numbers of worms $(1090,0=2)$ than female pupils $(879,0=1)$ in all the study areas. The overall direct prevalence for $A$. lumbricoides was $48.5 \%$ for the population that complied with faecal collection; and $30 \%$ for the total population enlisted for the study.

Table 1: Re-infection rate profile of Ascaris lumbricoides in the different LGAs

\begin{tabular}{|c|c|c|c|c|c|c|c|}
\hline LGA & $\begin{array}{l}\text { Initial worm } \\
\text { positive case } \\
(\%) \mathrm{Y}\end{array}$ & $\begin{array}{l}\text { No. treated } \\
\text { after } 6 \text { and } \\
7 \text { months }\end{array}$ & $\begin{array}{l}\text { No. } \\
\text { examined }\end{array}$ & $\begin{array}{l}\text { Young } \\
\text { worm ) } \\
\text { positive } \\
\text { case (\% } \\
\text { Yr }\end{array}$ & $\begin{array}{l}\text { No. } \\
\text { young } \\
\text { worms } \\
\text { voided }\end{array}$ & $\begin{array}{l}\text { Re- } \\
\text { infection } \\
\text { rate }(\%) \\
\text { ' } \mathrm{X} \text { ' in } \\
\text { months }\end{array}$ & $\begin{array}{l}\mathbf{N} \\
\text { in } \\
\text { months } \\
* * *\end{array}$ \\
\hline $\begin{array}{l}\text { Obafemi/ } \\
\text { Owode }\end{array}$ & 159 (62.6) & 245 & 224 & $20(8.2)$ & 26 & 4.2 & 22.9 \\
\hline Odeda & $81(44.7)$ & 222 & 174 & $10(4.5)$ & 15 & 2.3 & 25.4 \\
\hline $\begin{array}{l}\text { Ewekoro } \\
\text { Ado-odo/ }\end{array}$ & $67(34.2)$ & 217 & 196 & $7(3.2)$ & 10 & 1.6 & 25.9 \\
\hline Otta & $30(25.6)$ & 269 & 220 & $12(4.5)$ & 19 & 2.3 & 12.7 \\
\hline $\begin{array}{l}\text { Ogun } \\
\text { Waterside }\end{array}$ & 143 (59) & 284 & 232 & $21(7.4)$ & 32 & 3.8 & 21.8 \\
\hline Total & 480 & 1237 & 1046 & 70 & 102 & $0=2.8$ & $0=21.7$ \\
\hline
\end{tabular}

\footnotetext{
** Calculated from $\mathrm{X}=1-\sqrt{ } 1-\mathrm{Yr}$

${ }^{* * *}$ Calculated from $\mathrm{N}=\underline{\operatorname{In}(1-\mathrm{Y})}$

In $(1-X)$
} 


\section{Re-infection analysis}

From the 1237 pupils who participated in the study, a total of 102 young worms were voided by 70 young worm positive cases with a mean worm burden of 1.4 worms. The young worm positive rates in the study areas were in the range of 3.2 to $8.2 \%$. Of the initial 480 worm positive cases, 70 cases were positive for young worms (Table 1). Using the Psuedo-Code of the MONRATE tool, the calculated monthly reinfection rates $(X)$ for the LGAs were 1.6\% in Ewekoro, 2.3\% in Odeda, 2.3\% in Ado-odo/Otta, 3.8\% in Ogun Waterside and $4.2 \%$ in Obafemi/Owode. The mathematical mean of ' $X$ ' values for Ogun State was 2.8. The calculated reinfection time ( $\mathrm{N}$ months) for the LGAs varied from one area to another such as Ado-odo/Otta (12.7), Ogun Waterside (21.8), Obafemi/Owode (22.9), Odeda (25.4), and Ewekoro (25.9). The mean value for $\mathrm{N}$ in Ogun State was 21.7.

\section{Discussion}

The study showed that the overall prevalence by direct intensity of A. lumbricoides in Ogun State through the school system was $48.5 \%$. The study developed a descriptive tool "MONRATE" for determination of monthly reinfection rate and reinfection time in months. This algorithm, which is novel, was test run and used in the determination of the values obtained for the reinfection. The values obtained were the same but more accurate than the reinfection formula of Chai (1983) which served as the control.

The mean monthly reinfection rate calculated was 2.8 , which are approximately 3 months for schools in Ogun State. In assessing reinfection time for the State, an ' $\mathrm{N}$ months' mean value of 21.7 was obtained. The study adopted the use of mathematical means to develop an algorithm without altering the original contributions of Chai (1983) in the reinfection formula.

The significance of the new tool is realised with the development of information technology where computers are incorporated in our daily activities. It now becomes easier for programme control officers and epidemiologists to adapt the tool in calculating and predicting reinfection time. This also eliminates the stress basic biomedical practitioners go through in solving mathematical equations.

Anderson (1993) had opined that the important characteristic of highest responses to helminth infection is the density-dependent manner in which they act. The proportional reduction in establishment, survival and reproduction is greater in disease subpopulation of parasites than sparse ones. These processes act as negative feedback mechanism to constrain parasite population growth within individual host. Although immunological responses induce such effects, competition between parasites for finites resources within or on the host, may also be important.

Studies had posited that gastro-intestinal helminths are amenable to control in that they require no intermediate host, however the extent and prevalence of gastro-intestinal infections globally had continued to pose a major problem in recent decades (Molyneux, 1993). An integrated approach consisting of mass treatment, safe disposal of waste and provision of latrines in addition to the need for community and health education had been canvassed.

The result of this study is therefore a veritable instrument in the execution of control programmes involving mass treatment and health education at the private and community levels. Three months periodic treatment with anthelmintics would not only cut off re-infection time due to ascariasis but would also improve the morbidity status of the affected individual.

\section{Acknowledgements}

We sincerely appreciate the support and cooperation of Ogun State Primary Education Board, the Headteachers and parents. We thank the school pupils for participating in the study.

\section{References}

Adeyeba, O.A. \& Akintobi, A.M. (2002) Intestinal parasitic infections among school children in a Rural Community, Southwest Nigeria. Nigerian Journal of Parasitology 23, 11-18.

Agi, P.I. (1995) Pattern of infection of intestinal parasites in Sagbama community of the Niger Delta, Nigeria. West African Journal of Medicine 14, 39-42.

Anderson, R.M. \& May, R.M. (1985) Helminth infections of humans: Mathematical models, population dynamics and control. Advances in Parasitology 24, 1 -101.

Anderson, R.M. (1986) The population dynamics and epidemiology of intestinal nematode infections. Transactions of the Royal Society of Tropical Medicine and Hygiene 80, 686-696.

Anderson, R.M. (1993) Epidemiology. In: F.E.G. Cox (eds.), Modern Parasitology Blackwell, Oxford. p. 75-116.

Arfaa, F. \& Ghadirian, E. (1977) Epidemiology and mass-treatment of Ascariasis in six rural communities in central Iran. American Journal of Tropical Medicine and Hygiene 26, 866-871.

Asaolu, S.O., Holland, C.V., Jegede, J.O., Fraser, N.R., Stoddard R.C. \& Crompton, D.W.T. 
(1992) The prevalence and intensity of soil-transmitted helminthiases in rural communities in southern Nigeria. Annals of Tropical Medicine and Parasitology 86, 279- 287.

Chai, J.Y. (1983) Epidemiological studies on Ascaris lumbricoides re-infection in rural communities in Korea. 1. The relationship between prevalence and monthly re-infection rate. Korean Journal of Parasitology 21, 135-141.

Croll, N.A., Anderson, R.M., Gyorkos, T.W. \& Ghadirian, E. (1982) The population biology and control of $A$. lumbricoides in a rural community in Iran. Transactions of the Royal Society of Tropical Medicine and Hygiene 76, 187-197.

Fashuyi, S.A. (1992) The pattern of human intestinal helminth infection in farming communities in different parts of Ondo State, Nigeria. West Africa Journal of Medicine 11, 1317.

Forrester, J.E., Scott, M.E., Bundy, D.A.P. \& Golden, M.H.N. (1990) Predisposition of individuals and families in Mexico to heavy infection with $A$. lumbricoides and $T$. trichiura. Transactions of the Royal Society of Tropical Medicine and Hygiene 84, 272-276.

Hayashi, S. (1977) A model for the evaluation and assessment of the effect of control of the soiltransmitted helminthiases. Proceedings of the 4th APCO Conference, Tokyo: 297-311

Holland, C.V., Asaolu, S.O., Crompton, D.W.T., Stoddart, R.C., Macdonald, R. \& Torimiro, S.E.A. (1989) The epidemiology of $A$. lumbricoides and their soil transmitted helminths in primary school children from Ile-Ife, Nigeria Parasitology 99, 275-285.

Mafiana, C.F. (1995) Intestinal helminthiasis (with particular reference to Ascariasis) among school children in Ilewo-Orile, Ogun State, Nigeria. Nigerian Journal of Parasitology 16, 47-53.

Mafiana, C.F., Sodipe, M.B. \& Koleoso, B.I. (1998) Soil transmitted helminth parasites of humans in a city in southwestern Nigeria. Helminthologia 35, 203 -208.

Mafiana, C.F., Sam-Wobo, S.O. \& Akinsete, A. A. (2000) Epidemiology of Ascariasis in some rural communities in Ogun State, Nigeria. Global Journal of Pure and Applied Sciences 6, 23-26.

Molyneux, D.H. (1993) Control: In Modern Parasitology. F.E.G. Cox (Ed.) 2nd Edition, Blackwell Scientific Publications, Oxford.

Morishita, K. (1972) Studies on epidemiological aspects of ascariasis in Japan and basic knowledge concerning its control. Progress of Medical Parasitology in Japan 5, 145-213.
Obiamiwe, B.A. (1977) The pattern of parasitic infection in human out at the specialist hospital, Benin-city, Nigeria. Annals of Tropical Medicine and Parasitology 17, 35-17.

Ogbe, M.G. \& Odudu, L.A. (1988-90) Gastro intestinal helminthiasis in primary schools in Epe Local Government Area, Lagos State, Nigeria. Nigerian Journal of Parasitology 9-11, 95-106.

Ogbe, M.G. \& Adu, O.O. (1990) Intestinal helminthiasis in an orphanage in Nigeria. Bioscience Research Communication 2, 105-118.

Ogbe, M.G., Edet, E.E. \& Isichei, M.N. (2002) Intestinal helminth infection in primary school children in areas of operation of Shell Petroleum Development Coy of Nigeria (SPDC), Western Division in Delta State. Nigerian Journal of Parasitology 23, 3-10.

Okpala, I. (1956) The incidence of intestinal parasites among school children in Lagos, Nigeria. West African Medical Journal 5, 167170.

Onadeko, M.L. \& Ladipo, O.A. (1989) Intestinal parasitic infection in rural communities; a focus for primary health care in Nigeria. African Journal of Medicine 18, 289-294.

Ozumba, U.C. \& Ozumba, N. (2002) Pattern of helminth infections in the human gut at the University of Nigeria Teaching Hospital, Enugu, Nigeria. Journal of Health Science 48, 263-268.

Sam-Wobo, S.O. \& Mafiana, C.F. (2004) The effects of surface soil exchangeable cations on the prevalence of Ascaris lumbricoides in Ogun State, Nigeria. Nigerian Journal of Parasitology 25, 25-31.

Sam-Wobo, S.O., Mafiana, C.F. \& Idowu, A.B. (2004) Reinfection patterns of ascariasis among school children in Ogun State, Nigeria. Nigerian Journal of Parasitology 25, 7-13.

Suswam, E.A., Ogbogu, V.C., Umoh, J.U., Ogunsusi, R.A. \& Folaranmi, D.O.B. (1992) Intestinal parasites among school children in Sona and Igabi LGA of Kaduna State, Nigeria. Nigerian Journal of Parasitology 13, 39-42.

Reinthaler, F.F., Mascher, F., Klem, G. \& Sixl, W.(1988) A survey of gastrointestinal parasites in Ogun State, Southwest Nigeria. Annals of Tropical Medicine and Parasitology 82, 181-184.

Udonsi, J.K., Nwosu, A.B.C. \& Anya, A.O. (1980) Necator americanus: population structure, distribution and fluctuations in population densities of infective larvae in contaminated farmlands. Parasitology Research 63, 251-259. 